\title{
Faktor Risiko Terjadinya Preeklamsia Ibu Bersalin
}

\author{
Rismawati ${ }^{1}$, Soekidjo Notoatmodjo, Laila Ulfa \\ Program Studi Kesehatan Masyarakat Magister Universitas Respati Indonesia Jakarta \\ Email : Risma0225@gmail.com
}

\begin{abstract}
Abstrak
Dinegara maju kejadian preeklamsia pertahun mencapai 2-5\%. Tujuan umum penelitian ini adalah Mempelajari dan menjelaskan faktor risiko terjadinya preeklamsia. Jenis penelitian yang digunakan adalah penelitian case control. Populasi yang digunakan adalah seluruh ibu bersalin yang mengalami preeklamsia yaitu 1.896 dan ibu yang mengalami preeklamsia yaitu 272 . Jumlah sampel kontrol menggunakan perbandingan $1: 1$ yaitu kelompok kasus yang diambil dari data rekam medik dengan jumlah 272 ibu yang mengalami preeklamsia : kelompok kontrol dengan jumlah sampel yang diambil dari data rekam medik yaitu 272 ibu bersalin dari 1896. Cara pengambilan sampel kontrol yaitu dengan sampel secara acak sederhana (simple random sampling) yang menggunakan software randomizer. Terdapat hubungan antara umur, paritas, pendidikan, riwayat preeklamsia dan riwayat hipertensi dengan kejadian preeklamsia. Pada hasil multivariat Variabel yang dominan berhubungan dengan preeklamsia adalah riwayat preeklamsia, ibu yang memiliki riwayat preeklamsia mempunyai peluang untuk mengalami kejadian preeklamsia sebesar 2 kali lebih tinggi dibandingkan dengan ibu yang berada pada kelompok pasien yang tidak memiliki riwayat preeklamsia, setelah dikontrol oleh Umur, Paritas, Pendidikan dan riwayat hipertensi. Kesimpulan riwayat preeklamsia merupakan faktor penting terhadap terjadinya preeklamsia dan Ibu yang memiliki riwayat preeklamsia berpeluang besar untuk mengalami preeklamsia pada kehamilan selanjutnya.
\end{abstract}

Kata Kunci : : Preeklamsia, Ibu Bersalin

\begin{abstract}
In developed countries the incidence of preeclampsia per year reaches 2-5\%. The general objective of this research is to study and explain the risk factors for preeclampsia. The type of research used is case control research. The population used were all maternity mothers who experienced preeclampsia, namely 1,896 and mothers who experienced preeclampsia, namely 272. The number of control samples used a ratio of $1: 1$, namely the case group taken from medical record data with a total of 272 women experiencing preeclampsia: the control group with a total sample of taken from medical record data, namely 272 mothers who gave birth from 1896. The control sampling method was simple random sampling using randomizer software. There is a relationship between age, parity, education, history of preeclampsia and history of hypertension with the incidence of preeclampsia. In multivariate results, the dominant variable associated with preeclampsia is a history of preeclampsia, mothers who have a history of preeclampsia have a chance to experience the incidence of preeclampsia by 2 times higher than mothers who are in the group of patients who do not have a history of preeclampsia, after controlling for age, parity, Education and history of hypertension. Conclusion: history of preeclampsia is an important factor in the occurrence of preeclampsia and mothers who have a history of preeclampsia have a high chance of experiencing preeclampsia in subsequent pregnancies.
\end{abstract}

Keywords: Preeclampsia, Maternal Maternity

http://ejournal.urindo.ac.id/index.php/kesehatan

Article History :

Sumbitted 11 September 2020, Accepted 29 Juni 2021, Published 30 Juni 2021 


\section{Jurnal Bidang Ilmu Kesehatan}

\section{PENDAHULUAN}

Kesehatan Ibu dan Anak (KIA) adalah salah satu target yang ditentukan dalam SDGs 2030 tetapi angka kematian ibu, bayi dan balita di Indonesia masih tergolong tinggi dan merupakan salah satu masalah utama kesehatan. Kesehatan ibu dan Anak (KIA) adalah salah satu target dalam tujuan AGENDA 2030 (Sustainable Development Goals) yang ke-3 yaitu menargetkan Angka Kematian Ibu (AKI) 70 per 100.000 kelahiran hidup, Angka Kematian Bayi (AKB) maksimum 12 per 1000 kelahiran hidup dan angka kematian balita maksimum 25 per 1000 kelahiran hidup.

kejadian kasus kematian pada tahun 2016 di kabupaten/kota di provinsi banten yang tertinggi yaitu 59 kasus, Kabupaten Tangerang 57 kasus, Pandeglang 38 kasus, dan Lebak 28 kasus. Sedangkan kabupaten/kota dengan kasus kematian terendah adalah Kota Serang yaitu 10 kasus, Kota Tangerang Selatan 13 kasus, dan Kota Cilegon 16 kasus. (Profil Kesehatan Provinsi Banten, 2017)

Preeklampsia adalah salah satu masalah kesehatan yang sering terjadi pada kehamilan. Preeklampsia adalah penyebab timbulnya hipertensi dan adanya proteinuria pada umur kehamilan $>20$ minggu atau segera setelah persalinan. Preeklampsia adalah gangguan multisistem pada kehamilan (Fauziyah, 2016).

Dampak preeklamsia-eklamsia pada janin yaitu Berat Badan Lahir Rendah (BBLR) akibat spasmus arteriol spinalis deciduas menurunkan aliran darah ke plasenta, terjadinya Kerusakan pada plasenta ringan dapat menyebabkan hifoksia janin, keterbatasan pertumbuhan intrauterine (IUGR), dan jika kerusakan makin parah maka dapat berakibat prematurus, dismaturitas dan IUFD atau kematian janin dalam kandungan. Sedangkan dampak preeklamsia-eklamsia pada ibu yaitu solutio plasenta, abruption plasenta, hipofibrinogen, hemolisis, perdarahan otak, kerusakan pembuluh kapiler mata hingga kebutaan, odema paru, nekrosis hati, kerusakan jantung, sindrom HELLP, kelainan ginjal, komplikasi terberat terjadinya preeklamsiaeklamsia adalah kematian ibu. (Devi, Fiki 2015).

\section{METODE PENELITIAN}

Pada penelitian ini Jenis penelitian yang digunakan adalah case control. Populasi pada penelitian ini yaitu seluruh ibu bersalin yang mengalami preeklamsia yaitu 1896 dan yang tidak mengalami preeklamsia yaitu 272 di RSUD Berkah Pandeglang tahun 2019. Jumlah sampel kontrol pada penelitian ini menggunakan perbandingan 1 : 1 yaitu kelompok kasus yang diambil dari data rekam medik dengan jumlah 272 : kelompok kontrol dengan jumlah sehingga sampel kontrol yang diambil dari data rekam medik yaitu 272 ibu bersalin. Untuk menentukan sample kontrol 272 dari 1.869 ibu bersalin yang tidak mengalami preeklamsia yaitu menggunakan teknik pengambilan sampel secara acak sederhana (simple random sampling) yang menggunakan randomizer dan sistem random sampling. 
Jurnal Bidang Ilmu Kesehatan

Tabel 1

Distribusi frekuensi terjadinya freeklamsia berdasarkan Umur, Pendidikan, Paritas, Riwayat Preeklamsia dan Riwayat Hipertensi

\begin{tabular}{|c|c|c|c|c|c|c|}
\hline \multirow{3}{*}{ Variabel } & \multicolumn{2}{|c|}{ Kejadian Preeklampsia } & \multicolumn{2}{|c|}{ Kejadian Preeklampsia } & \multirow{3}{*}{ n (544) } & \multirow{3}{*}{$\%$} \\
\hline & \multicolumn{2}{|c|}{ Kasus } & \multicolumn{2}{|c|}{ Kontrol } & & \\
\hline & $\begin{array}{c}n \\
(272)\end{array}$ & $\%$ & $\begin{array}{c}n \\
(272)\end{array}$ & $\%$ & & \\
\hline \multicolumn{7}{|l|}{ Umur } \\
\hline Berisiko & 167 & 61,4 & 143 & 52,6 & 310 & 69,4 \\
\hline Tidak Berisiko & 105 & 38,6 & 129 & 47,4 & 234 & 30,6 \\
\hline \multicolumn{7}{|l|}{ Paritas } \\
\hline Berisiko & 111 & 40,8 & 85 & 31,4 & 196 & 36,1 \\
\hline Tidak Berisiko & 161 & 59,2 & 187 & 68,6 & 347 & 63,9 \\
\hline \multicolumn{7}{|l|}{ Pendidikan } \\
\hline Rendah & 116 & 42,6 & 141 & 51,8 & 257 & 47,2 \\
\hline Tinggi & 156 & 57,4 & 131 & 48,2 & 287 & 52,8 \\
\hline \multicolumn{7}{|c|}{ Riwayat Preeklampsia } \\
\hline Ada & 98 & 36,0 & 65 & 23,9 & 163 & 30,0 \\
\hline Tidak ada & 174 & 64,0 & 207 & 76,1 & 381 & 70,0 \\
\hline \multicolumn{7}{|l|}{ Riwayat Hipertensi } \\
\hline Ada & 69 & 25,4 & 43 & 15,8 & 112 & 20,6 \\
\hline Tidak ada & 203 & 74,6 & 229 & 84,2 & 432 & 79,4 \\
\hline
\end{tabular}




\section{Jurnal Bidang Ilmu Kesehatan}

Berdasarkan tabel 1 pada varibel umur menunjukan bahwa persentase responden terbanyak pada kelompok kasus yaitu responden yang berisiko ( $<20$ tahun $>35$ tahun) yaitu $61,4 \%$. pada kelompok kontrol persentase terbanyak adalah berisiko ( $<20$ tahun $>35$ tahun) yaitu $52,6 \%$.

Variabel Paritas pada tabel 1 menunjukan bahwa persentase responden terbanyak pada kelompok kasus terbanyak yaitu responden yang berisiko (primipara) yaitu $40.8 \%$. Pada kelompok kontrol persentase responden terbanyak adalah yang tidak berisiko (multipara dan grandemultipara) yaitu $68.6 \%$.

hasil analisis univariat pada tabel 1 variabel pendidikan menunjukan bahwa persentase terbanyak pada kelompok kasus yaitu yang berpendidikan tinggi (SMA-PT) yaitu $57.4 \%$. Sedangkan pada kelompok kontrol persentase terbanyak yaitu pada responden yang berpendidikan rendah yaitu $51.8 \%$. variabel riwayat preeklamsia pada tabel 1 menunjukan bahwa persentasi paling banyak pada kelompok kasus yaitu pada responden yang tidak ada riwayat preeklamsia yaitu 64.0\%. pada kelompok kontrol persentase terbanyak yaitu pada responden yang tidak memiliki riwayat preeklamsia yaitu $64.0 \%$.

Berdasarkan tabel 1 variabel riwayat hipertensi menunjukan bahwa persentasi terbanyak yaitu pada responden yang tidak ada riwayat hipertensi yaitu $74.6 \%$. Pada kelompok kontrol persentasi terbanyak yaitu pada responden yang tidak ada riwayat hipertensi yaitu $74.6 \%$. 
Tabel 2

Distribusi ibu menurut variabel independen dan dependen pada kejadian preeklamsia

\begin{tabular}{|c|c|c|c|c|c|c|c|c|}
\hline \multirow{3}{*}{ Variabel } & \multicolumn{4}{|c|}{ Kejadian Preeklampsia } & \multirow{3}{*}{$\begin{array}{c}n \\
(544)\end{array}$} & \multirow{3}{*}{$\%$} & \multirow[b]{3}{*}{ OR (95\%Cl) } & \multirow[b]{3}{*}{$P$ value } \\
\hline & \multicolumn{2}{|c|}{ Kasus } & \multicolumn{2}{|c|}{ Kontrol } & & & & \\
\hline & n (272) & $\%$ & n (272) & $\%$ & & & & \\
\hline \multicolumn{9}{|l|}{ Umur } \\
\hline Berisiko & 167 & 61,4 & 143 & 52,6 & 311 & 57,2 & $(1,005-1,988)$ & 0,057 \\
\hline Tidak Berisiko & 105 & 38,6 & 129 & 47,4 & 233 & 42,8 & 1,414 & \\
\hline \multicolumn{9}{|l|}{ Paritas } \\
\hline Berisiko & 111 & 40,8 & 85 & 31,4 & 194 & 35,7 & $(1,028-2,083)$ & 0,043 \\
\hline Tidak Berisiko & 161 & 59,2 & 187 & 68,6 & 349 & 64,3 & 1,463 & \\
\hline \multicolumn{9}{|l|}{ Pendidikan } \\
\hline Rendah & 116 & 42,6 & 141 & 51,8 & 257 & 47,2 & $(1032-2,030)$ & 0,039 \\
\hline Tinggi & 156 & 57,4 & 131 & 48,2 & 287 & 52,8 & 1,447 & \\
\hline \multicolumn{9}{|l|}{ Riwayat PE } \\
\hline Ada & 98 & 36,0 & 65 & 23,9 & 163 & 30,0 & $(1,236-2,604)$ & 0,003 \\
\hline Tidak ada & 174 & 64,0 & 207 & 76,1 & 381 & 70,0 & 1,794 & \\
\hline \multicolumn{9}{|c|}{ Riwayat Hipertensi } \\
\hline Ada & 69 & 25,4 & 43 & 15,8 & 112 & 20,6 & $(1,183-2,769)$ & 0,008 \\
\hline Tidak ada & 203 & 74,6 & 229 & 84,2 & 432 & 79,4 & 1,180 & \\
\hline
\end{tabular}




\section{Jurnal Bidang Ilmu Kesehatan}

hasil uji statistic pada tabel 2 menunjukan bahwa umur ibu yang berisiko pada kasus sebanyak $61,4 \%$ dan kontrol 52,9\%. Hasil uji chi square diperoleh nilai $p$ value 0,05 yaitu $\leq 0,05$, sehingga terdapat hubungan yang signifikan antara umur dengan kejadian preeklamsia dengan demikian hipotesis diterima. Ibu yang memiliki umur berisiko dan tidak berisiko memiliki peluang yang sama untuk mengalami preeklamsia

Berdasarkan tabel 2 bahwa paritas yang berisiko pada kelompok kasus yaitu sebanyak $40,1 \%$ dan pada kelompok kontrol $31,6 \%$. Hasil uji chi square dipoleh nilai $p$ value 0,049 yaitu $<0,05$, sehingga terdapat hubungan yang signifikan antara paritas dengan kejadian preeklamsia dengan demikian hipotesis diterima. Ibu dengan paritas berisiko memiliki peluang 2 kali untuk mengalami preeklamsia dibandingkan dengan ibu dengan paritas yang tidak berisiko.

hasil uji bivariate pada tabel 2 bahwa ibu yang memiliki pendidikan rendah pada kelompok kasus yaitu 57,0\% dan pada kelompok kontrol $48,2 \%$. Hasil uji chi square diperoleh nilai $P$ Value 0,048 yaitu $<0,05$, sehingga terdapat hubungan yang signifikan antara pendidikan dengan kejadian preeklamsia dengan demikian hipotesis diterima.
Ibu yang memiliki pendidikan tinggi dan pendidikan rendah memiliki peluang yang sama untuk mengalami preeklamsia.

Berdasarkan tabel 2 bahwa ibu yang memiliki riwayat preeklamsia pada kelompok kasus yaitu $36,0 \%$ dan kelompok kontrol $23,9 \%$. Hasil uji chi square diperoleh nila $p$ value 0,003 yaitu $<0,05$, sehingga terdapat hubungan yang signifikan antara riwayat preeklamsia dengan kejadian preeklamsia dengan demikian hipotesis diterima. Ibu yang memiliki riwayat preeklamsia memiliki peluang 2 kali untuk mengalami preeklamsia dibandingkan dengan ibu yang tidak memiliki riwayat preeklamsia.

Bahwa ibu yang memiliki riwayat hipertensi pada kelompok kasus sebanyak 25,4\% dan pada kelompok kontrol 15,8\%. Hasil uji Chi Square diperoleh nilai $p$ Value 0,006 yaitu $<0,05$, sehingga terdapat hubungan yang signifikan antara riwayat hipertensi dengan kejadian preeklamsia dengan demikian hipotesis diterima. Ibu yang memiliki riwayat hipertensi memiliki peluang 2 kali untuk mengalami preeklamsia dibandingkan dengan ibu yang tidak memiliki riwayat hipertensi 
Tabel 3

Pemodelam Regresi Logistik Multivariat Terakhir yaitu seperti abortus, anemia, kurang gizi, preeklamsia dan eklamsia. (Manuaba, 2010). Penelitian lain yang dilakuka.n oleh Fatmawati, dkk (2017). Berdasarkan kelompok umur,

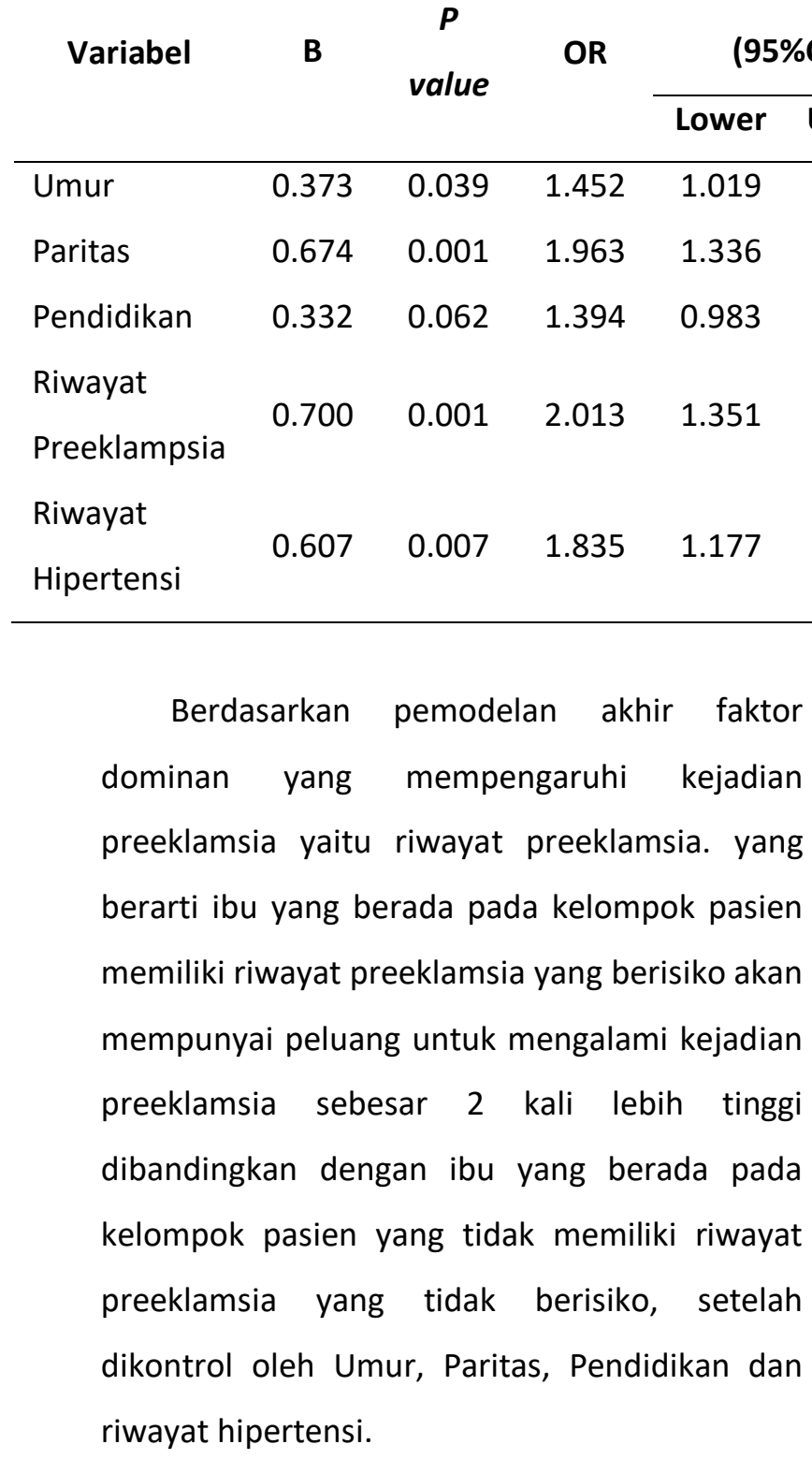

\section{PEMBAHASAN}

\section{Faktor risiko terjadinya preeklamsia}

Pada kejadian pernikahan dini sangat berisiko untuk terjadinya preeklamsia karena secara biologis pada remaja terjadi proses awal kamatangan organ reproduksi manusia, dampaknya apabila terjadi kehamilan pada usia remaja akan banyak risiko yang akan dihadapi kejadian preeklampsia/eklampsia di RSUD Kabupaten Gresik yaitu pada ibu yang memiliki umur $<20$ tahun dan $>35$ tahun. Ibu yang memiliki usia muda atau tua berpengaruh 2 kali, 2.883 dimana terhadap derajat preeklampsia/eklampsia dibandingkan dengan 2.999 ibu usia produktif. Usia produktif dari seorang wanita adalah 20-35 tahun. Usia refroduktif ini 2.860 merupakan periode yang paling aman untuk hamil dan melahirkan karena pada usia tersebut risiko terjadinya komplikasi selama kehamilan lebih rendah. Pada usia $>35$ tahun terjadi proses degeneratif yang mengakibatkan perubahan structural dan fungsional yang terjadi pada pembuluh darah, sehingga lebih rentan mengalami preeklamsia. Usia $<20$ tahun mempunyai risiko terjadinya preeklamsia 3,58 kali lebih besar dibandingkan berusia 20-35 tahun. Hal ini terjadi karena fisik dan psikis pada seorang wanita yang usianya terlalu muda belum siap dalam menghadapi kehamilan dan persalinan (Denantika, 2013). Kesimpulannya umur sangat berpengaruh terhadap kejadian preeklamsia karena ibu yang memiliki umur $<20$ tahun, organ reproduksinya belum siap untuk dibuahi dan belum matang sehingga akan mengakibatkan beberapa masalah kesehatan pada saat wanita tersebut hamil dan melahirkan. begitu juga dengan ibu yang memiliki umur $>35$ tahun, organ reproduksinya telah melemah sehingga dapat berdampak pada 
kesehatannya bila wanita tersebut hamil dan melahirkan.

Ibu yang memiliki paritas yang rendah lebih baik dari yang berparitas tinggi, terdapat asosiasi (Notoatmodjo, 2011). Sedangkan penelitian lain yg dilakukan oleh Suriani Tahir dan Daswati (2017). Ibu dengan graviditas risiko tinggi memiliki peluang sebesar 6 kali lebih besar mengalami preeklampsia dibandingkan ibu dengan graviditas risiko rendah dan penelitian lain yang dilakukan oleh Fatkiyah, dkk (2016). Faktor paritas (anak pertama) berisiko mengalami preeklampsia sebesar 1 kali dibandingkan ibu hamil yang kedua atau lebih (multiparitas). Kesimpulannya adalah ibu yang paritasnya berisiko yaitu primipara memiliki risiko 1 kali dari pada ibu yang paritasnya tidak berisiko yaitu menurut teori Sudhaberata, multipara dan grandemultipara dikarenakan ibu yang paritasnya berisiko yaitu pada ibu yang primipara terjadi pembentukan blocking antibodies terhadap antigen tidak sempurna sehingga dapat menghambat invasi arteri spirallis ibu oleh trofoblas sampai batas tertentu sehingga mengganggu fungsi plasenta. Akibatnya sekresi vasodilator prostasiklin oleh sel-sel endoteal palsenta berkurang dan sekresi trobosan bertambah sehingga terjadi vasokontriksi generallisata dan sekresi aldosterone menurun hal ini dapat mengakibatkan terjadinya preeklamsia.

Pendidikan ibu didapat seiring dengan kemajuan ilmu dan teknologi serta adanya emansipasi wanita di Indonesia untuk mendapatkan hak dan kewajiban disegala bidang terutama pendidikan. Pendidikan seseorang sangat mempengaruhi dengan kesempatan seseorang tersebut dalam menyerap informasi mengenai pencegahan komplikasi dalam kehamlan maupun persalinan terutama tentang kejadian preeklamsia (Djanah, 2010). Berdasarkan penelitian yang dilakukan oleh Sarasawati, dkk (2016). Responden yang menderita preeklampsia yang berpendidikan rendah belum tentu memiliki pengetahuan yang rendah pula, hal ini dikarenakan mereka mendapat pengetahuan dari penyuluhan yang dilakukan oleh bidan desa dalam acara PKK desa atau arisan desa yang biasa dilakukan setiap sebulan sekali sehingga mereka cenderung memperhatikan kesehatannya dengan melakukan pemeriksaan antenatal secara lengkap. Kesimpulannya adalah ibu yang berpendidikan diharapkan dapat menerapkan segala pengetahuan yang didapat dan bisa mengaplikasikan pengetahuan tersebut untuk menjaga kesehatan ibu dan bayinya dan dapat memperhatikan kesehatannya. Ibu yang memiliki pendidikan tinggi juga memiliki pengetahuan yang baik untuk mencegah segala komplikasi dalam kehamilan dan persalinan sehingga ibu dapat memeriksakan kehamilannya secara rutin untuk menghindari segala komplikasi yang ada.

Faktor riwayat preeklamsia menurut teori varney (2006) salah satu penyebab preeklamsia adalah predisposisi genetic, atas dasar tersebut riwayat preeklamsia pada keluarga dan individu merupakan faktor risiko untuk terjadinya preeklamsia pada kehamilan selanjutnya. 
Terdapat bukti bahwa preeklamsia merupakan penyakit yang diturunkan, penyakit ini lebih sering ditemukan pada anak wanita dari ibu penderita preeklamsia atau mempunyai riwayat preeklamsia/eklamsia dalam keluarga (Manuaba, 2012). Berdasarkan penelitian yang dilakukan oleh Saraswati, dkk (2016). Bahwa responden yang memiliki riwayat preeklampsia sebelumnya mempunyai risiko 20 kali mengalami kejadian preeklampsia dibandingkan dengan responden yang tidak memiliki riwayat preeklampsia. Penelitian yang dilakukan oleh Rozikhan (2007). ibu yang mengalami hamil preeklampsia mempunyai risiko 8 kali untuk terjadi terjadi preeklampsia berat dibandingkan dengan seorang ibu hamil yang tidak ada riwayat preeklampsia. Kesimpulannya adalah ibu yang pernah menderita preeklamsia pada kehamilan sebelumnya memiliki risiko untuk mengalami preeklamsia pada kehamilan selanjutnya. Atas dasar teori yang telah dibahas mengenai preeklamsia, bahwa preeklamsia adalah predisposisi genetik baik dari individu maupun dari keluarga yang mengalami preeklamsia, sehingga dapat menimbulkan risiko penyakit turunan (genetik).

Faktor riwayat hipertensi pada sebagian wanita dengan riwayat hipertensi kronis, hipertensi dapat memperburuk terutama pada kehamilan seperti itu dapat disertai dengan proteinuria atau oedema patologis dan kemudian disebut superimposed preeclamsia. Kerap kali superimposed preeclamsia timbul lebih awal dalam kehamilan bila dibandingkan dengan preeklamsia murni dan cenderung jadi berat pada kebanyakan kasus (Cuningham, 2013). Sedangkan penelitain yang dilakukan oleh Fatkiyah N, dkk (2017). Ibu yang memiliki riwayat hipertensi memiliki risiko 6 kali untuk mengalami preeklamsia. Penelitian lain yang dilakukan oleh Situmorang, dkk (2016). ibu hamil yang mengalami hipertensi mempunyai risiko 2 kali untuk terjadi terjadi preeklampsia berat dibandingkan dengan seorang ibu hamil yang tidak ada riwayat hipertensi. Kesimpulannya adalah ibu yang mempunya riwayat hipertensi cenderung akan mengalami preeklamsia terutama pada pada ibu dengan riwayat hipertensi kronis sehingga pada kehamilan selanjutnya dapat memperburuk kehamilannya seperti hipertensi yang disertai dengan proteinuria dan oedema, hal tersebut yang dapat menyebabkan terjadinya preeklamsia.

\section{KESIMPULAN}

Ibu yang memiliki riwayat preeklamsia memiliki risiko besar untuk mengalami preeklamsia pada kehamilan selanjutnya.

\section{DAFTAR PUSTAKA}

Provinsi

Banten

tahun

2013.https://dinkes.bantenprov.go.id/upl oad/article doc/TABEL PROFIL PROV BA NTEN 2013.pdf (diakses pada tanggal 07 agustus 2020, pukul 14.50 WIB)

(Hubungan Antara Usia Dengan Preeklamsia Pada Ibu Hamil di POLI KIA RSUD Kefamenanu Kabupaten Timor Tengah Utara.

(Diakses dari 
http://akbidharapanmulya.ac.id/atm/kon ten/editor/samples/jurnal/file_jurnal/t__2 2.pdf) Diaksespadatanggal 11-02-2020 pukul 12.45Wib

Karima, dkk. 2015. Hubungan Faktor Risiko Dengan Kejadian Preeklamsia Berat di RSUP Dr. M. Djamil Padang. (Diakses dari http://jurnal.fk.unand.ac.id/index.php/jka /article/download/299/281) Diakses Diakses pada tanggal 12 Februari 2020 pukul 10.05 Wib

(Kementerian Kesehatan Republik Indonesia, 2016).

Notoatmodjo S. 2012. Metodologi Penelitian Kesehatan. Jakarta: PT Rineka Cipta.

Manuaba, dkk. 2010. Ilmu Kebidanan Penyakit Kandungan dan KB. Jakarta; EGC

Mochtar, Rustam. 2015. Sinopsis Obstetri, Jakarta; EGC

Umar, Mareza Yolanda, 2017. Faktor-Faktor yang Berhubungan dengan Kejadian Preeklampsia pada Perempuan Bersalin. Jurnal IImu Kesehatan 2

Rukiyah, Ai Yeyeh, LiaYulianti. 2014. Asuhan Kebidanan Patologi Kebidanan. Jakarta. Trans Info Media
Rozikhan. (2007). Faktor-Faktor Risiko Terjadinya Preeklampsia Berat Di Rumah Sakit dr. H. Soewondo Kendal. Journal Universitas Diponegoro Semarang. Tersedia dalam eprints.undip.ac.id/18342/1/ROZIKHAN.p df. Diakses pada tanggal 20 April 2020 pukul 10.00 wib

Sarwono Prawirohardjo Hipertensi Dalam Kehamilan. Dalam: Ilmu Kebidanan (Edisi 4). Jakarta: Bina Pustaka Sarwono Prawiroharjo. 2014.)

Sumarah, dkk. "Perawatan Ibu Bersalin (Asuhan Kebidanan Pada lbu Bersalin)". Yogyakarta: Fitramaya; 2010

WHO, 2019. https://www.who.int/gho/en/. Diakses pada tanggal 11-02-2020 pukul 10.10 wib

Nathiqotul fatkiyah dan kodiyah masturoh, Determinan maternal kejadian preeklamsia (studi kasus di kabupaten Tegal, Jawa Tengah). Tersedia dalam http://iks.fikes.unsoed.ac.id/index.php/ik s/article/view/642. Diakses pada tanggal 20 April 09.00 WIB). 